\title{
Changes in serum adenosine deaminase and isoenzyme levels in addition to routine liver biochemical parameters in sheep with chronic fascioliasis
}

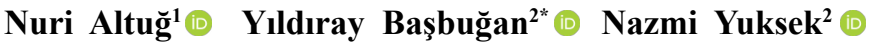 \\ ${ }^{1}$ Department of Internal Medicine, Faculty of Veterinary Medicine, Tekirdağ Namık Kemal University, Tekirdağ, Turkey. \\ 2Department of Internal Medicine, Faculty of Veterinary Medicine, Van Yuzuncu Y1l University, 65080, Van, Turkey. E-mail: yildiraybasbugan@gmail.com. \\ "Corresponding authors.
}

ABSTRACT: This study assessed changes in the levels of adenosine deaminase (ADA) and its isoenzymes in addition to routine liver biochemical parameters in sheep with fascioliasis. The study was conducted on 35 Akkaraman sheep. Of these, 25 sheep were diagnosed with fascioliasis based on anamnesis and clinical signs, and had endoparasites based on parasitological examinations (Fasciola-infected group). The remaining 10 sheep that were sampled from a single healthy herd (same flock) different from the infected group did not have any clinical signs or endoparasites (control group). Total protein (TP), albumin (ALB), and globulin (GLB) levels gradually increased on days after treatment compared to the values measured before treatment; the increases were statistically significant on all days for TP levels but only on day 14 after treatment for GLB levels $(P<0.05)$. Although, the ALB levels did not increase significantly on days after treatment, the ALB level and $A L B / G L B$ ratio on days 7 and 14 after treatment were still lower than the values of day 21 after treatment and control group $(P<$ 0.05). Total bilirubin (T-Bil) and direct bilirubin (D-Bil) levels on days 14 and 21 were significantly lower than that of day 0 (before treatment) and day 7 after treatment $(P<0.05)$. These results indicated that the increase in adenosine deaminase $(A D A)$ and ADA1 levels may be due to possible concomitant infection of Fasciola larvae (in the parenchyma) and adults (in the bile duct).

Key words: adenosine deaminase, biochemistry, diagnosis, Fasciola spp., sheep.

\begin{abstract}
Alterações nos níveis séricos de adenosina desaminase e isoenzima em relação aos parâmetros bioquímicos de rotina do fígado de ovinos com fasciolíase crônica
\end{abstract}

RESUMO: Este estudo teve como objetivo avaliar as alterações nos niveis de adenosina desaminase (ADA) e suas isoenzimas, além de parâmetros bioquímicos hepáticos de rotina em ovinos com fasciolíase. O estudo foi realizado em 35 ovinos $s$ Akkaraman. Destes, 25 ovinos foram suspeitas de ter fascioliase com base na anamnese e sinais clínicos, e diagnosticados com endoparasitas com base em exames parasitológicos (grupo de estudo). Os 10 ovinos restantes que foram amostrados no mesmo rebanho não apresentavam quaisquer sinais clínicos ou endoparasitas (grupo controle). Os níveis de proteina total (TP), albumina (ALB) e globulina (GLB) aumentaram gradualmente nos dias após o tratamento em comparação com os valores antes do tratamento; os aumentos foram estatisticamente significativos em todos os dias para os níveis de TP, mas apenas após o dia 14 de tratamento para os níveis de $G L B(P<0,05)$. Embora os níveis de ALB não tenham aumentado significativamente após os dias de tratamento, o nível de ALB e a razão ALB / GLB após o tratamento nos dias 7 e 14 ainda eram menores do que após o tratamento no dia 21 e os valores do grupo de controle $(P<0,05)$. Os níveis de bilirrubina total (T-Bil) e bilirrubina direta (D-Bil) nos dias 14 e 21 após o tratamento foram significativamente menores do que os valores do dia 7 antes do tratamento e após o tratamento $(P<0,05)$. Estes resultados indicam que o aumento nos níveis de adenosina desaminase $(A D A)$ e ADA1 pode ser devido à possível infecção concomitante de larvas de Fasciola (no parênquima) e adultos (nos dutos).

Palavras-chave: adenosina desaminase, bioquímica, diagnóstico, Fasciola spp., ovinos.

\section{INTRODUCTION}

Fascioliasis is a zoonotic disease caused by the trematode Fasciola hepatica, the most common liver fluke. This disease is frequently observed in ruminants in tropical and subtropical regions (TAYLOR, 2012; IBRAHIM, 2017). Although, the causative agent can mainly infect cattle and sheep, its pathogenic effect is particularly higher in sheep
(TAYLOR, 2012) and results in high morbidity and mortality leading to significant economic losses due to various reasons, such as sudden death or poor growth rate, as well as poor productive performance (ROJO-VÁZQUEZ et al., 2012; IBRAHIM, 2017).

Clinical fascioliasis can be classified as acute, subacute, or chronic according to the number and stage of flukes present in sheep (MITCHELL, 2002; ROJO-VÁZQUEZ et al., 2012). Acute

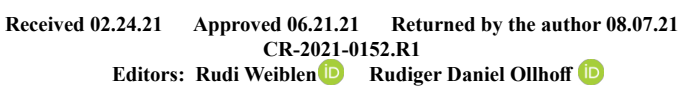


fascioliasis is the parenchymal phase characterized by acute liver failure. It is often accompanied by hemorrhage due to parenchymal damage caused by the migration of several juvenile flukes (which are large enough to cause mechanical damage to the liver) after the ingestion of several metacercariae (MITCHELL, 2002; IBRAHIM, 2017). Subacute fascioliasis is an advanced stage that follows the acute form; it can be fatal, with many juvenile flukes being present in the liver parenchyma and many adult flukes being present in the bile ducts (MITCHELL, 2002; ROJO-VÁZQUEZ et al., 2012). Chronic fascioliasis, conversely, is a biliary phase that causes cholangitis, bile duct obstruction, fibrosis, plasma protein leakage from the epithelium, and complete blood loss due to the nutritional activity of flukes after the establishment of adult parasites in the bile ducts (MITCHELL, 2002; ROJO-VÁZQUEZ et al., 2012; IBRAHIM, 2017). Although, laboratory findings vary according to the stage of the disease anemia, eosinophilia, hypoalbuminemia, and increased liver enzyme levels are commonly detected in infected sheep (MITCHELL, 2002; ROJO-VÁZQUEZ et al., 2012; IBRAHIM, 2017).

Adenosine deaminase (ADA), a key enzyme involved in purine metabolism, is an aminohydrolase that catalyzes irreversible hydrolytic deamination of adenosine and deoxyadenosine to inosine and deoxyinosine, respectively. Two isoenzymes of ADA have been identified: ADA1 and ADA2. ADA is localized in the lymph nodes, spleen, intestines, thymus, kidney, heart, lung, liver and capillary cells. Its levels can be determined using serum or plasma samples (ALTUG et al., 2009). Serum ADA levels increased in cattle with liver damage and diseases (CHIKUMA, 1997; YASUDA et al., 2001; ABD-ELLAH et al., 2004), in dogs with hepatopathies (TANABE, 1993) and liver damage due to carbon tetrachloride toxicity (ALTUG AND AGAOGLU, 2000) and in other domestic animals with diseases, such as leucosis (YASUDA et al., 1996), white muscle disease (RODRIGEZ \& GONZALEZ 1975; ALTUG et al., 2006) and theileriosis (ALTUG et al., 2008). Changes in serum ADA levels have been found to be useful in the differential diagnosis of liver damage and biliary obstruction in human (LAKSHMI et al., 2015; KAKI \&TUMMA, 2016). High ADA and ADA1 isoenzyme levels can be detected in serum samples in the presence of acute liver destruction and dysfunction, while high ADA and ADA2 isoenzyme levels can be detected in the presence of chronic liver diseases (KURATA, 1995). Both isoenzymes of ADA are present in healthy sheep (ALTUG et al.,
2009). Although, the ADA activity increased in sheep with liver damage due to experimental chronic copper toxicity and acute carbon tetrachloride toxicity (HUNT \&MCCOSTER, 1970), no study has simultaneously evaluated the levels of serum ADA and its isoenzymes in sheep with natural fascioliasis. This study determined the changes in the levels of ADA and its isoenzymes in addition to routine liver biochemical parameters during endoparasitic treatment in sheep with fascioliasis.

\section{MATERIALS AND METHODS}

\section{Animals and protocols}

The study involved 35 Akkaraman sheep aged of 1-4 years old, reared in different regions and ranches in the province of Van. Two groups were established; Fasciola-infected group and clinically healthy (control group). For this purpose, sheep from different farms with suspected fascioliasis were determined based on anamnesis and clinical findings such as weight loss, edema under the jaw and pallor of the conjunctival mucosa. All sheep included in the study were fecal sampled by removing feces from rectum twice at a 7 day interval. Samples were examined for the presence of Fasciola spp eggs by the flotation-centrifuge method (URQUART et al., 1996). The sheep with only Fasciola spp. eggs on fecal examinations were included in Fasciolainfected group $(n=25)$ and blood sampled on day 0 before treatment which consisted of oral use of $10 \mathrm{mg} /$ $\mathrm{kg}$ triclabendazole $+7.5 \mathrm{mg} / \mathrm{kg}$ levamisole (Levatrizol ${ }^{\text {TM }}$ Vetas $^{\circledR}$, Turkey) and after the treatment on the $7^{\text {th }}, 14^{\text {th }}$ and $21^{\text {st }}$ days. The control group $(n=10)$ was from a single healthy herd (same flock which had no health problem on clinical and biochemical examination and no endoparasites (including Fasciola spp) on fecal examination) different from the infected group. Blood samples were collected once from the control group. The normality of the enzyme and biochemical parameters of the control group was evaluated by comparing with the results of previous studies (ALTUG et al., 2009; YUKSEK et al., 2013) conducted with the same methodology in healthy animals in the region. The study protocol was approved by Animal Researches Local Ethics Committee, Van Yüzüncü Y1l University (2020/02).

\section{Laboratory analysis}

Serum glucose, total protein (TP), albumin (ALB), total bilirubin (T-Bil), direct bilirubin (D-Bil), aspartate aminotransferase (AST), alanine aminotransferase (ALT), alkaline phosphatase (ALP), 
gamma-glutamyl-transferase (GGT) and lactate dehydrogenase levels were biochemically measured using an autoanalyzer (Architect ci $16200^{\circledR}$, Abbott, U.S.A), while glutamate dehydrogenase (GLDH) levels were spectrophotometrically (Photometer $5010^{\circledR}$, Boehringer Mannheim, Germany) measured using a commercial test kit. Globulin (GLB), ALB / GLB and indirect bilirubin (I-Bil) were calculated. Serum adenosine deaminase (ADA) levels were spectrophotometrically measured using the method described by GIUSTI \&GALANTI, (1984), and serum ADA isoenzyme levels were measured using the method of UNGERER et al., (1994).

\section{Statistical analysis}

Descriptive statistics for all parameters were expressed as the mean and standard deviation (Mean \pm SD). Repeated-measure analysis of variance was performed to compare the changes in the parameters by group over time. Tukey multiple comparison test was performed to determine intergroup differences. A $\mathrm{P}$ value $<0.05$ was considered statistically significant. The SPSS (ver. 13) statistical software was used for statistical analysis.

\section{RESULTS}

Table 1 shows the levels of ADA, isoenzymes, and some liver biochemical parameters of the both groups. In the Fasciola-infected group, ADA, ADA1, ALP, GGT, T-Bil and D-Bil levels were higher than the control group, while TP and ALB levels and ALB / GLB ratio were lower $(\mathrm{P}<0.05)$. T-Bil and D-Bil levels on day 7; ADA and ADA1 levels on days 7 and 14; and ALP and GGT levels on days 7, 14, and 21 were higher in the Fasciola-infected group $(\mathrm{P}<$ 0.05), while ALB level and ALB/GLB ratio on days 7 and 14 were lower in the Fasciola-infected group than the control group $(\mathrm{P}<0.05)$ (Table 1).

ADA and ADA1 levels determined on days 7 and 14 were lower than the values determined before treatment in the Fasciola-infected group (P

Table 1 - Levels of adenosine deaminase, its isoenzymes, and some biochemical parameters in sheep with the Fasciola-infected and control group $(\mathrm{Mean} \pm \mathrm{SD})$

\begin{tabular}{|c|c|c|c|c|c|}
\hline \multirow[t]{3}{*}{ Parameters } & \multirow[t]{3}{*}{ Control $(\mathrm{n}=10)$} & \multicolumn{4}{|c|}{ 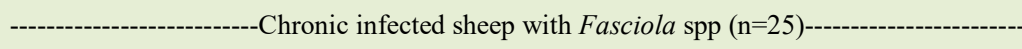 } \\
\hline & & \multirow{2}{*}{$\begin{array}{l}\text { Before Treatment } \\
0 \text {. day }\end{array}$} & \multicolumn{3}{|c|}{---------------------------------After Treatment------------------------------- } \\
\hline & & & 7. day & 14. day & 21.day \\
\hline Total ADA (IU/L) & $8.22 \pm 1.51^{\mathrm{a}}$ & $17.17 \pm 4.91^{\# \mathrm{~b}}$ & $9.81 \pm 1.87^{\mathrm{b} \dagger}$ & $10.45 \pm 3.16^{\mathrm{b} \dagger}$ & $8.20 \pm 1.41^{*}$ \\
\hline ADA $1(\mathrm{IU} / \mathrm{L})$ & $7.36 \pm 1.66^{\mathrm{a}}$ & $16.13 \pm 4.73^{\text {\#b }}$ & $9.21 \pm 1.48^{\mathrm{b} \dagger}$ & $9.23 \pm 3.00^{\mathrm{b} \dagger}$ & $7.55 \pm 1.35^{*}$ \\
\hline ADA $2(\mathrm{IU} / \mathrm{L})$ & $0.88 \pm 0.38$ & $1.03 \pm 0.70$ & $0.59 \pm 0.72$ & $1.21 \pm 0.80$ & $0.65 \pm 0.51$ \\
\hline GLDH (IU/L) & $2.79 \pm 0.87$ & $4.77 \pm 5.46$ & $4.49 \pm 4.19$ & $2.79 \pm 2.63$ & $3.01 \pm 1.50$ \\
\hline $\operatorname{AST}(\mathrm{IU} / \mathrm{L})$ & $49.8 \pm 7.38^{\mathrm{a}}$ & $44.4 \pm 17.9$ & $40.6 \pm 15.6$ & $45.6 \pm 6.50$ & $31.2 \pm 10.5^{\mathrm{b}}$ \\
\hline $\operatorname{ALT}(\mathrm{IU} / \mathrm{L})$ & $19.5 \pm 2.27$ & $16.10 \pm 8.96$ & $19.9 \pm 5.25$ & $19.8 \pm 9.90$ & $17.9 \pm 4.72$ \\
\hline LDH (IU/L) & $688.4 \pm 163.4^{\mathrm{a}}$ & $593.5 \pm 172.0$ & $493.5 \pm 155.8^{b}$ & $528.1 \pm 195.6$ & $463.5 \pm 191.9^{b}$ \\
\hline GGT (IU/L) & $23.8 \pm 16.7^{\mathrm{a}}$ & $73.6 \pm 46.4^{\mathrm{b}}$ & $57.5 \pm 50.2^{\mathrm{b}}$ & $41.8 \pm 15.5^{\mathrm{b}}$ & $42.3 \pm 10.7^{b}$ \\
\hline $\operatorname{ALP}(\mathrm{IU} / \mathrm{L})$ & $43.4 \pm 15.3^{\mathrm{a}}$ & $177.9 \pm 91.9^{\mathrm{b}}$ & $93.4 \pm 65.5^{\mathrm{b}}$ & $141.0 \pm 44.7^{\mathrm{b}}$ & $112.4 \pm 58.6^{\mathrm{b}}$ \\
\hline $\mathrm{TP}(\mathrm{g} / \mathrm{dl})$ & $6.41 \pm 0.15^{\mathrm{a}}$ & $4.42 \pm 0.76^{\mathrm{b} \#}$ & $5.99 \pm 1.03^{*}$ & $6.32 \pm 1.93^{*}$ & $6.12 \pm 1.08^{*}$ \\
\hline $\operatorname{ALB}(g / d l)$ & $2.63 \pm 0.45^{\mathrm{a}}$ & $1.43 \pm 0.62^{\mathrm{b}}$ & $2.06 \pm 0.57^{\mathrm{b}}$ & $1.95 \pm 0.53^{b}$ & $2.31 \pm 0.37$ \\
\hline GLB (g/dl) & $3.78 \pm 0.38^{\mathrm{a}}$ & $2.99 \pm 0.72^{\mathrm{b}^{*}}$ & $3.93 \pm 1.07$ & $4.37 \pm 1.73^{\#}$ & $3.81 \pm 1.09$ \\
\hline ALB/GLB rate & $0.70 \pm 0.05^{\mathrm{a}}$ & $0.48 \pm 0.05^{\mathrm{b}}$ & $0.52 \pm 0.03^{b}$ & $0.45 \pm 0.02^{b}$ & $0.61 \pm 0.03$ \\
\hline Glucose (mg/dl ) & $59.7 \pm 24.5$ & $52.5 \pm 10.3$ & $53.1 \pm 5.28$ & $51.1 \pm 9.01$ & $45.6 \pm 7.33$ \\
\hline T-Bil (mg/dl) & $0.86 \pm 0.10^{\mathrm{a}}$ & $1.77 \pm 0.20^{\# \mathrm{~b}}$ & $1.85 \pm 0.26^{\text {\#b }}$ & $1.07 \pm 0.20^{*}$ & $1.02 \pm 0.59^{*}$ \\
\hline D-Bil (mg/dl) & $0.74 \pm 0.08^{\mathrm{a}}$ & $1.60 \pm 0.19^{\# \mathrm{~b}}$ & $1.69 \pm 0.25^{\# \mathrm{~b}}$ & $0.95 \pm 0.15^{*}$ & $0.87 \pm 0.16^{*}$ \\
\hline I-Bil (mg/dl ) & $0.12 \pm 0.05$ & $0.17 \pm 0.01$ & $0.15 \pm 0.01$ & $0.12 \pm 0.04$ & $0.15 \pm 0.04$ \\
\hline
\end{tabular}

Different letters in the same line (a-b) compared to the control group. indicates that the difference observed on the days before and after treatment is statistically significant $(\mathrm{P}<0.05)$.

Different signs in the different row $\left[\left(\dagger_{-} \#\right)(\#-*)\left(\dagger_{-}^{*}\right)\right]$. indicates that the difference between before treatment and after treatment days is statistically significant $(\mathrm{P}<0.05)$.

ADA: Adenosine Deaminase. ALB: Albumin. ALP: Alkaline Phosphatase. ALT: Alanine Aminotransferase. AST: Aspartate Aminotransferase. D-Bil: Direct Bilirubin. GGT: Gamma-Glutamyl-Transferase. GLB: Globulin. GLDH: Glutamate Dehydrogenase. IBil: Indirect Bilirubin. LDH: Lactate Dehydrogenase. T-Bil: Total Bilirubin. Total Protein (TP). 
$<0.05)$ but were still higher than the values of day 21 values $(\mathrm{P}<0.05)$. ALP and GGT levels, which were high before treatment, gradually decreased on after treatment days, but the difference was not significant. However, these values were higher than the values of control group. TP, ALB, and GLB levels gradually increased on days post treatment compared to the values before treatment; the increases were statistically significant on all days for TP levels but only on day 14 for GLB levels $(\mathrm{P}<0.05)$. The ALB level did not differ after treatment days. The ALB/ GLB ratio was lower on days 7 and 14 after treatment than that of day 21. Moreover, T-Bil and D-Bil levels on days 14 and 21 after treatment were significantly lower than the values determined before treatment and day 7 after treatment $(\mathrm{P}<0.05)$.

\section{DISCUSSION AND CONCLUSIONS}

Fascioliasis may affect liver parenchyma, bile ducts, or both, depending on the stage of the disease. Changes indicative of the part of liver affected, such as parenchyma, bile duct, can be detected by assessing the associated laboratory parameters (MITCHELL, 2002; ROJO-VÁZQUEZ et al., 2012; IBRAHIM, 2017). ADA were reported to be localized within the liver tissue, (TANABE, 1993) blood lymphoid cells (CHECHIK et al., 1983; BAGANHA et al., 1990) and structure of Fasciola spp. (ALI, 2008). Therefore, this study have assessed the serum levels of ADA, its isoenzymes and routine biochemical parameters and focused on interpreting their association with the area of involvement (hepatocellular region and / or even ducts) in cases with fascioliasis.

GLDH, ornithine carbamoyltransferase and sorbitol dehydrogenase are reported to be the most specific markers of liver damage in sheep with fascioliasis (BRAUN et al., 2010). Of these, GLDH is especially considered to be a useful and specific marker of hepatocellular damage (MILNE \&SCOTT, 2006; BRAUN et al., 2010). Although, they are not liver-specific, the levels of other enzymes, such as AST (MILNE \&SCOTT, 2006), LDH (MILNE \&SCOTT, 2006) and ALT (BRAUN et al., 2010) can also be evaluated in sheep. Increased GLDH and AST levels are observed in acute fascioliasis during the parenchymal migration of juvenile forms of $F$. hepatica (MITCHELL, 2002; BRAUN et al., 2010; IBRAHIM, 2017) the levels decrease with the entry of adult forms into the bile ducts (BRAUN et al., 2010; IBRAHIM, 2017). In this study; although, a gradual increase was observed only in GLDH levels, indicating liver damage in sheep with fascioliasis, this increase was not statistically significant. Similarly, other enzymes such as AST, ALT and LDH, which were reported as indicators of the severity or progression of hepatic injury (MILNE \&SCOTT, 2006), did not differ between the values of the Fasciola-infected group before treatment and the control group (Table 1). This indicated that the disease was not in the parenchymal phase at the time of evaluation, in accordance with the findings of previous studies (BRAUN et al., 2010; IBRAHIM, 2017).

As in other ruminants, GGT is suggested to be a marker of chronic changes, such as cholestasis and epithelial damage of the biliary duct, in sheep with fascioliasis, and the GGT level has increased significantly with the entry of the adult form of $F$. hepatica into the bile ducts (MITCHELL, 2002; ROJO-VÁZQUEZ et al., 2012; HODŽIĆ et al., 2013; IBRAHIM, 2017). Although, not as important as GGT, ALP can also be used as a marker of cholestasis (MILNE \&SCOTT, 2006; BRAUN et al., 2010). Similar to previous findings, (MITCHELL, 2002; MILNE \&SCOTT, 2006; BRAUN et al., 2010; ROJO-VÁZQUEZ et al., 2012; HODŽIĆ et al., 2013; IBRAHIM, 2017) an increase in levels of serum GGT and ALP was observed before treatment in this study (Table 1). It has been reported that GLDH is the best marker of hepatocellular damage, while GGT is the best marker of cholestasis in cases with fascioliasis. The increased GLDH and GGT levels are indicative of the acute and chronic stages of the disease, respectively (MITCHELL, 2002; MILNE \&SCOTT, 2006; ROJO-VÁZQUEZ et al., 2012). However, both GLDH and GGT levels increase in subacute fascioliasis (SCOTT et al., 2005). In this study; although, there was no increase in GLDH levels, the obvious increase in GGT levels confirmed the presence of chronic fascioliasis, in accordance with previous findings (SCOTT et al., 2005; MILNE \&SCOTT, 2006; ROJO-VÁZQUEZ et al., 2012).

The levels of serum T-Bil and its subfractions was reported to increase in fascioliasis (FERRE et al., 1995; BOONE et al., 2005; HODŽIĆ et al., 2013). The T-Bil level increases as a result of increased bilirubin production due to increased hemolytic toxin production by liver flukes (TELEB et al., 2007). The concurrent increase in D-Bil and T-Bil is an indicator of bile duct obstruction and intrahepatic cholestasis in chronic fascioliasis (FERRE et al., 1995; BOONE et al., 2005; HODŽIĆ et al., 2013). In this study, hyperbilirubinemia was detected due to the increase in direct bilirubin levels on day 0 and day 7 after treatment. This condition indicated the biliary phase of fascioliasis (biliary obstruction) and can be 
evaluated by assessing the levels of enzymes that are markers of cholestasis.

Hypoproteinemia (TELEB et al., 2007; YÜKSEK et al., 2007; YUKSEK et al., 2013; EL-AZIEM HASSEM \&MOHAMED 2017), hypoalbuminemia and hyperglobulinemia(EL-; MILNE \&SCOTT, 2006; ROJOVÁZQUEZ et al., 2012; TELEB et al., 2007; YÜKSEK et al., 2013 AZIEM HASSEM \&MOHAMED, 2017) is the frequently reported laboratory finding in fascioliasis. However, previous studies stated that the decrease in ALB / GLB ratio, which is a common finding in subacute (SCOTT et al., 2005) and chronic (HAROUN et al., 1986; SYKES et al., 1980) fascioliasis, should also be evaluated. The results of this study (Table 1) were similar to those of previous studies in terms of levels of serum TP and its subfractions (MILNE AND SCOTT, 2006; MATANOVIĆ et al., 2007; TELEB et al., 2007; YUKSEK et al., 2007; ROJO-VÁZQUEZ et al., 2012; YUKSEK et al., 2013) and the ALB/GLB ratio (MATANOVIĆ et al., 2007). ELAZIEM HASSEM \&MOHAMED (2017) reported that hypoproteinemia and hypoalbuminemia are indicative of liver tissue destruction and fibrosis, cholangitis, and biliary obstruction, while hyperglobulinemia might be indicative of an increase in $\beta$-GLB production by immune cells in response to infection.

Serum levels of the enzymes BUN, ALB, and GLB are reliable markers of the disease stage and severity (MATANOVIĆ et al., 2007). Moreover, an increase in plasma enzyme activity is associated with the parasite load (RAADSMA et al., 2008), while a decrease in plasma enzyme activity can be used for monitoring the treatment efficacy in sheep with fascioliasis (GAASENBEEK et al., 2001). SCOTT et al. (2005) reported that rapid improvements in liver weight, serum protein levels, and AST levels were indicative of the efficacy of triclabendazole. However, in this study, GGT and ALP levels on day 21 after treatment in the Fasciola-infected group were significantly higher than the values of control group, while the levels of TP and its sub-fractions were largely normalized, similar to the findings of SCOTT et al. (2005) (Table 1).

Studies (BAGANHA et al., 1990; UNGERER et al., 1994; ALTUG \&AGAOGLU, 2007) have demonstrated that ADA plays an important role in the regulation of immune responses and that its isoenzymes have diagnostic significance in determining the cellular origin of immune responses. Lymphocytes and neutrophils contain ADA1 but not ADA2. Both these isoenzymes are present in monocytes and macrophages (BAGANHA et al., 1990; UNGERER et al., 1994; GAKIS, 1996; ALTUG
\&AGAOGLU, 2007). Increased ADA levels have been observed in domestic animals with liver injuries (HUNT \&MCCOSTER, 1970; TANABE, 1993; ALTUG \&AGAOGLU, 2000) and diseases such as feline infectious peritonitis (TANABE, 1993), bovine leucosis (TANABE, 1993; CHIKUMA, 1997), glycogen degeneration, liver abscess, sawdust liver, fatty liver (YASUDA et al., 2001; ABD-ELLAH et al., 2004). These increases have been reported to either be positively correlated with (ABD-ELLAH et al., 2004) or not be associated with (CHIKUMA, 1997) the degree of hepatocellular damage. CHIKUMA, (1997) reported that the increased enzyme levels observed in liver diseases were related to the immune response of mononuclear cells as well as hepatocellular damage in cattle. In this study, an obvious increase was observed in serum ADA and ADA1 levels on day 0 in the Fasciola-infected group; these values significantly decreased on days 7 and 14 after treatment but did not differ from the values of control group and that of day 21 after treatment (Table 1). While no increase was observed in the levels of enzymes that are markers of hepatocellular damage, laboratory findings revealed that the disease was in the biliary obstruction phase of the chronic stage (Table 1). Thus, unlike previous studies (ALTUG \&AGAOGLU, 2000; ABD-ELLAH et al., 2004), the increase observed in ADA and ADA1 levels cannot be directly associated with increased hepatocellular damage in this study. In addition, no study has evaluated the relationship of ADA with both hepatocellular damage and biliary obstruction in domestic animals. However, human studies examining ADA levels in patients with hepatocellular damage and biliary obstruction have reported that ADA activity is generally normal in patients with extrahepatic or biliary obstruction but is significantly increased in the case of hepatic involvement (LAKSHMI et al., 2015; KAKI \&TUMMA, 2016). Thus, considering previous findings, (LAKSHMI et al., 2015; KAKI \&TUMMA, 2016) increased ADA and ADA1 levels observed in sheep with chronic fascioliasis cannot be directly associated with biliary obstruction in this study. ABD-ELLAH et al., (2004) observed increased activity of ADA and liver enzymes, such as GGT and GLDH, in cattle with liver diseases and suggested that the increased ADA activity could have originated from immune cells as ADA is not an enzyme that leaks from the liver. The increase in GLB levels is known to be indicative of the immune response in cases with fascioliasis (MATANOVIĆ et al., 2007; ROJO-VÁZQUEZ et al., 2012; EL-AZIEM HASSEM AND MOHAMED, 2017). In this study, it was observed that serum GLB levels increased 
gradually after treatment compared to the values of before treatment and control group and approached the control group values on the 7th day and was statistically significant compared to that of the 14th day before treatment. However, ALB levels and ALB / GLB ratio were lower than the control group values until the 21st day (Table 1). The increase in specific immunoglobulin (IgG and IgA) levels is commonly observed in fascioliasis (NANSEN et al., 1975). In experimental infections, it was reported that serum IgG and IgA reached maximal values in 8 weeks after inoculation, especially the increase in IgG was more obvious, and then decreased slowly (FERRE et al., 1997). In addition, serum GGT activity is strongly associated with IgG levels (BRITTI et al., 2005; BRAUN et al., 2010). In this study, before treatment serum GGT activity was significantly higher in the Fasciola-infected group than in the control group; although, the activity gradually decreased after treatment, it was still significantly higher than the activity in the control group even on day 21 after treatment (Table 1).

However, in this study; although, GGT levels decreased after treatment compared to before treatment, an increase in GLB levels was observed. Therefore, the increase in GGT levels in this study cannot be associated with the immune response in the context of GLB levels. For this reason, in the light of previous findings (SCOTT et al. 2005), the increase in the levels of serum protein and its sub-fractions after treatment can be considered to indicate the efficacy of triclabendazole treatment. Moreover; although, the GGT levels decreased on all days after the treatment, it was determined that the Fasciola-infected group had still higher values than the control group values. This finding is similar to the findings of SCOTT et al., (2005), that reported the high levels in GLDH and GGT continued for 4 weeks after triclabendazole treatment in sheep with subacute fascioliasis.

In the light of the above literature, the increased serum ADA and ADA1 levels observed in this study may be due to possible concomitant infection of Fasciola larvae in the liver parenchyma and adults in the ducts (RUSHTON 1977; RADOSTITS et al., 2006). Although, high after treatment GGT levels in this study confirmed bile lesions in animals, the parameters examined did not completely exclude the possibility of parenchymal damage. Because, in the infected group compared to the control group, ALB level (day 0) was lower before the treatment and GLDH levels were - higher, though not statistically significant (Table 1). This situation may be explained by the dynamic natural re-infection process in the rangelands as reported by the authors (RUSHTON 1977; TINAR and KORKMAZ 2003; RADOSTITS et al., 2006). Sheep may receive new parasitic loads on a daily basis, so they may show new infections (to a lesser extent - parenchymal effect) in the sampling period after treatment and late liver infections on the sampling on day 0 (before treatment). In conclusion, increased ADA and ADA1 levels do not seem to be directly associated with increased immune response to the chronic fascioliasis in sheep. However, ADA and ADA1 levels that gradually decrease over the course of treatment; although, higher than the control group, may be associated with steadily decreasing GGT and gradually rising GLB levels over the same period. It would be beneficial to evaluate the detailed changes in ADA and ADA1 levels along with the changes in the levels of inflammatory markers, immunoglobulins, rutin haematologic and biochemical parameters at different stages of fascioliasis.

\section{ACKNOWLEDGEMENTS}

This study was supported by the Scientific Research Projects Commission of Van Yüzüncü Y1l University (Project No: TAP-2019-8333).

\section{BIOETHICS AND BIOSSECURITY COM- MITTEE APPROVAL}

The study protocol was approved by Animal Researches Local Ethics Committee, Van Yüzüncü Yıl University (protocol number 2020/02).

\section{DECLARATION OF CONFLICT OF INTEREST}

The authors declare no conflict of interest. The founding sponsors had no role in the design of the study; in the collection, analyses, or interpretation of data; in the writing of the manuscript, and in the decision to publish the results.

\section{AUTHORS' CONTRIBUTIONS}

All authors contributed equally for the conception and writing of the manuscript. All authors critically revised the manuscript and approved of the final version.

\section{REFERENCES}

ABD-ELLAH, M. R. A., et al., Serum adenosine deaminase activity in bovine liver diseases. J Vet Med Sci, v.66, n.11, p.14211422, 2004. Available from: <https://www.jstage.jst.go.jp/article/ jvms/66/11/66_11_1421/_article>. Accessed: Jul. 23. 2021. Epub 07- Dec- 2004. doi: 10.1292/jvms.66.1421.

ALI, EMM. Fasciola gigantica: purification and characterization of adenosine deaminase. Exp Parasitol, v.119, n.2, p.285-290, 2008. 
Available from: <https:/www.sciencedirect.com/science/article/ abs/pii/S0014489408000635?via\%3Dihub>. Accessed: Jul. 23. 2021. doi: 10.1016/j.exppara.2008.03.004.

ALTUG, N, et al. Adenosine deaminase in the diagnosis of white muscle diseases in lambs. Med Weter, v.62, n.9: p.1007-1010, 2006. Available from: <http://www.medycynawet.edu.pl/images/stories/ pdf/pdf2006/09/20069s10071010.pdf>. Accessed: Jul. 23. 2021.

ALTUG, N, AGAOGLU ZT. Investigation on the relationship between lymphocyte subsets, immunoglobulin levels and adenosine deaminase activities in immunosuppressive dose methylprednisolone treated dogs. B Vet I Pulawy, v.51, n.1, p.109-115. 2007. Available from: <https:/www.infona.pl/resource/ bwmeta 1.element.agro-article-dd1e95aa-9527-4b44-a2119b07eebf0782>. Accessed: Jul. 23. 2021.

ALTUG, N, AGAOGLU ZT. Serum adenosine deaminase activity in dogs: It's importance in experimental liver intoxication, Isr. J. Vet. Med, v.55, n.4, p.129-134, 2000. Available from: <https:// www.cabdirect.org/cabdirect/abstract/20013028868>. Accessed: Jul. 23. 2021.

ALTUG, N, et al. Serum adenosine deaminase activity in domestic animals: Reference values. Turk J Vet Anim Sci, v.33, n.2, p.137-141, 2009. Available from: <https://journals.tubitak.gov.tr/ veterinary/abstract.htm?id=10113 $>$. Accessed: Jul. 23. 2021.

ALTUG, N, et al. Determination of adenosine deaminase activity in cattle naturally infected with Theileria annulata. Trop Anim Health Pro, v.40, n.6, p.449-456, 2008. Available from: <https:// link.springer.com/article/10.1007/s11250-007-9119-9>. Accessed: Jul. 23. 2021.

BAGANHA, M. F., et al. Serum and pleural adenosine deaminase: correlation with lymphocytic populations. Chest, v.97, n.3, p.605-610, 1990. Available from: <https://doi.org/10.1378/ chest.97.3.605>. Accessed: Jul. 23. 2021.

BOONE, L, et al. Selection and interpretation of clinical pathology indicators of hepatic injury in preclinical studies. Vet Clin Path, v.34, n.3, p.182-188, 2005. Available from: $<$ https://doi.org/10.1111/j.1939165X.2005.tb00041.x>. Accessed: Jul. 23. 2021.

BRAUN, J. P., et al. Clinical biochemistry in sheep: A selected review. Small Ruminant Res, v.92, n.1-3, p.10-18, 2010. Available from: $\quad<$ https://doi.org/10.1016/j.smallrumres.2010.04.002>. Accessed: Jul. 23. 2021.

BRITTI, D, et al. Evaluation of serum enzyme activities as predictors of passive transfer status in lambs. J. Am. Vet. Med. Assoc, v.226, p.951-955, 2005. Available from: <https://avmajournals.avma.org/ doi/pdf/10.2460/javma.2005.226.951>. Accessed: Jul. 23. 2021.

CHECHIK, B. E, et al. Localization and identity of adenosine deaminasepositive cells in tissues of the young rat and calf. Hictochem. J, v.15, p.373-387, 1983. Available from: <https://link.springer.com/ article/10.1007\%2FBF01002970>. Accessed: Jul. 23. 2021.

CHIKUMA, S. Clinicopathological studies of serum adenosine deaminase activity in cattle, Jpn. J. Vet. Res, v.45, n.2, p.125126, 1997. Available from: <http://hdl.handle.net/2115/4628>. Accessed: Jul. 23. 2021.

EL-AZIEM HASHEM, M. A, MOHAMED, S. S. Hazard assessments of cattle fascioliasis with special reference to hemato- biochemical biomarkers. Vet Med Open J, v.2, n.1, p.12-18, 2017. Available from: <http://dx.doi.org/10.17140/VMOJ-2-111>. Accessed: Jul. 23. 2021

FERRE, I. et al. The effects of subclinical fasciolosis on hepatic secretory function in sheep. Parasitol Res, v.81, n.2, p.127-131, 1995. Available from: <https://link.springer.com/article/10.1007/ BF00931617>. Accessed: Jul. 23. 2021.

FERRE, I, et al. Serum and bile antibody responses (IgG and IgA) during subclinical Fasciola hepatica infection in sheep. Vet. Parasitol, v.68, p.261-267, 1997. Available from: <https:// doi.org/10.1016/S0304-4017(96)01070-9>. Epub 29-May-1998. Accessed: Jul. 23. 2021.

GAASENBEEK, C. P., et al. An experimental study on triclabendazole resistance of Fasciola hepatica in sheep. Vet. Parasitol, v.95, p.37-43. 2001. Available from: <https://doi. org/10.1016/S0304-4017(00)00413-1>. Accessed: Jul. 23. 2021.

GAKIS, C. Adenosine deaminase (ADA) isoenzymes ADA 1 and ADA 2: diagnostic and biological role, Eur. Respir. J, v.9, p.632-633, 1996. Available from: <https://erj.ersjournals. com/content/9/4/632.short>. Accessed: Jul. 23. 2021. doi: 10.1183/09031936.96.09040632.

GIUSTI, G, GALANTI, B. Colorimetric Method, in "Methods of Enzymatic Analysis", Editor, HU Bergmeyer, 3rd Ed., Verlag Chemie; p.315-323, Weinheim. 1984.

HAROUN, E. M., GAMEEL, A. A. Studies on naturally occurring ovine fascioliasis in the Sudan. Helminthol, v.60, p.47-53, 1986. Available from: <https://www.cambridge.org/ core/journals/journal-of-helminthology/article/abs/studies-onnaturallyoccurring-ovine-fascioliasis-in-the-sudan/1415445944 FF7EDEBD7FA16DF4AEF3D9>. Accessed: Jul. 23. 2021. doi: $10.1017 / \mathrm{S} 0022149 \mathrm{X} 0000821 \mathrm{X}$.

HODŽIĆ, A, et al. Influence of Fasciola hepatica on serum biochemical parameters and vascular and biliary system of sheep liver. Iran $\mathbf{J}$ Parasitol, v.8, n.1, p.92. 2013. Available from: <https://www.ncbi.nlm. nih.gov/pmc/articles/PMC3655246/>. Accessed: Jul. 23. 2021.

HUNT, S, MCCOSKER PJ. Observations on serum adenosine deaminase activity in experimentally produced liver diseases of cattle and sheep: yellow-wood, lantana, carbon tetrachloride and chronic copper poisoning. BRIT VET J, v.126, v.2, p.74-81, 1970. Available from: <https://doi.org/10.1016/S0007-1935(17)485101>. Accessed: Jul. 23. 2021.

IBRAHIM, N. Fascioliasis: systematic review. ABR, v.11, n.5, p.278-285, 2017. Available from: <https://www.researchgate.net/ profile/Nuraddis-Ibrahim/publication/319644294_Fascioliasis Systematic_Review/links/59b79598458515c212b45d12/ Fascioliasis-Systematic-Review.pdf $>$. Accessed: Jul. 23. 2021. doi: 10.5829/idosi.abr.2017.278.285.

KAKI, S. B, TUMMA, S. N. A study of serum adenosine deaminase levels and liver function tests in liver disorders. JEMDS, v.5, n.95, p.6996-7000, 2016. Available from: $<$ https://go.gale.com/ps/anonymous ?id=GALE $\%$ 7CA $474042435 \&$ sid $=$ googleScholar\&v=2.1\&it=r\&linkac cess $=$ abs\&issn $=22784748 \& p=A O N E \& s w=w>$. Accessed: Jul. 23. 2021.

KURATA, N. Adenosine deaminase, Nippon Rinsho, v.53, n.5, p.1178-1183, 1995. Available from: <https://europepmc.org/ article/med/7602776>. Accessed: Jul. 23. 2021. 
LAKSHMI, V. B, et al. Serum adenosine deaminase levels in hepatic disorders. IJBAMR, v.4, n.4, p.23-31. 2015 Available from: $<$ https://www.ijbamr.com/assets/images/issues/pdf/September $\% 20$ 2015\%20\%2023-31.pdf.pdf $>$. Accessed: Jul. 23. 2021.

MATANOVIĆ, K, et al. Hematological and biochemical changes in organically farmed sheep naturally infected with Fasciola hepatica. Parasitol Res, v.101, n.6, p.1657-1661, 2007. Available from: $\quad<$ https://link.springer.com/article/10.1007/s00436-0070709-2>. Epub 13- Aug- 2007. Accessed: Jul. 23. 2021.

MILNE, E, SCOTT, P. Cost-effective biochemistry and haematology in sheep. In practice, v.28, n.8, p. 454-461, 2006 Available from: <https://doi.org/10.1136/inpract.28.8.454>. Accessed: Jul. 23. 2021.

MITCHELL, G. Update on fasciolosis in cattle and sheep. In Practice, v.24, n.7, p.378-385, 2002. Available from: $<$ https://doi. org/10.1136/inpract.24.7.378>. Accessed: Jul. 23. 2021.

NANSEN, $\mathrm{P}$ et al., Immunoglobulins in Fasciola hepatica infected ruminants. In: OVER, H.J., ARMOUR, J. (Eds.), Facts and Reflections. Workshop on Fascioliasis, Lelystad, v.2, p.65-72, 1975.

RAADSMA, H. W, et al. Host responses during experimental infection with Fasciola gigantica and Fasciola hepatica in Merino sheep. II. Development of a predictive index for Fasciola gigantica worm burden. Vet. Parasitol, v.154, p.250-261, 2008. Available from: <https://doi.org/10.1016/j.vetpar.2008.03.018>. Accessed: Jul. 23. 2021

RADOSTITS, et al. Veterinary Medicine E-Book: A textbook of the diseases of cattle, horses, sheep, pigs and goats. $10^{\text {th }}$ Edition. Elsevier Health Sciences, 2006. p.1576-1579.

RODRIGUEZ, J. Z, GONZALEZ, J. G. Activities of enzymes involved in energy metabolism of Churra breed lambs, and changes caused by enzootic muscular dystrophy, Ann. Fac. Vet. Leon.; v.21, n.21, p.409-419, 1975.

ROJO-VÁZQUEZ, F. A, et al. Update on trematode infections in sheep. Vet parasitol, v.189, n.1, p.15-38, 2012. Available from: <https://doi. org/10.1016/j.vetpar.2012.03.029>. Accessed: Jul. 23. 2021.

RUSHTON, B. Ovine fascioliasis following reinfection. Research in veterinary science, v.22, n.1, p.133-134, 1977. Availeble from: $<$ https://www.sciencedirect.com/science/article/abs/pii/ S0034528818333319>. Accessed: Jul. 23. 2021.

SCOTT, P. R, et al. An outbreak of subacute fasciolosis in Soay sheep: ultrasonographic biochemical and histological studies. The Veterinary Journal, v.170, n.3, p.325-331, 2005. Available from: $<$ https://doi.org/10.1016/j.tvj1.2004.08.010>. Accessed: Jul. 23. 2021.
SYKES, A. R, et al. Chronic subclinical fascioliasis in sheep: effects on food intake, food utilisation and blood constituents. Res Vet Sci, v.28, p.63-70, 1980. Available from: $<$ https://www. sciencedirect.com/science/article/abs/pii/S0034528818327747>. Epub 16-Nov-2018. Accessed: Jul. 23. 2021

TANABE, T. Adenosine deaminase activities in the sera and tissues of animals and their clinical significance, Jpn. J. Vet. Res, v.41, n.1, 1993. Available from: <http://hdl.handle.net/2115/2443>. Accessed: Jul. 23. 2021.

TAYLOR, M. A. Emerging parasitic diseases of sheep. Vet parasitol, v.189, n.1, p.2-7, 2012. Available from: <https://doi. org/10.1016/j.vetpar.2012.03.027>. Accessed: Jul. 23. 2021.

TELEB, D. F, et al. Effect of fascioliasis on hematological, serum biochemical and histopathological changes in sheep. EJSGS, v.2, n.2, p.18-36, 2007. Available from: <https://journals.ekb.eg/articl e_27991_537738d132a7ff440f9de888c7a7ddb0.pdf $>$. Accessed: Jul. 23. 2021.

TINAR, R, KORKMAZ, M. Fasciolosis. ISBN:975-94646-4-0. Türkiye Parazitoloji Derneği, yayın No: 8. İzmir, 2003, p:107-206.

UNGERER, J. P. J., et al. Significance of adenosine deaminase activity and its isoenzymes in tuberculous effusions. Chest, v.106, n.1, 33-37, 1994. Available from: <https://doi.org/10.1378/ chest.106.1.33>. Accessed: Jul. 23, 2021.

URQUART, G. M,. Veterinary Parasitology, $2^{\text {nd }}$ edition, Blackwell Scientific Publications, Oxford, UK, 1996.

YASUDA, J, et al. Bovine serum adenosine deaminase activity and inflammatory change of the liver, Vet. Biochem, v.38, n.2, p.33-37, 2001. Available from: <https://ci.nii.ac.jp/naid/10026882091/>. Accessed: Jul. 23, 2021.

YASUDA J, et al. Adenosine deaminase (ADA) activity in tissues and sera from normal and leukaemic cattle, Br. Vet. J, v.152, n.4, p.485-488, 1996. Available from: <https://doi.org/10.1016/S00071935(96)80044-3>. Epub 19-Nov-2007. Accessed: Jul. 23. 2021.

YUKSEK, N, et al. Enhancement of the glucose metabolism and the reverse cholesterol transport by a peroxisome proliferator receptor $\alpha(\mathrm{PPAR} \alpha)$ agonist included in the fasciolosis treatment in naturally infested sheep. Revue Méd. Vét, v.164, n.4, p.163172, 2013. Available from: <https:/www.revmedvet.com/2013/ RMV164 163 172.pdf>. Accessed: Jul. 23. 2021.

YUKSEK, N, et al. Koyunlarda endoparazit enfeksiyonlarında triklabendazol-levamizol kombinasyonunun tedavi etkinliği. Van Vet J, v.18, p.19-24, 2007. Available from: < https://dergipark.org. tr/en/download/article-file/146588>. Accessed: Jul. 23. 2021. 